\title{
Arthur Collins's The Nature of Mental Things
}

\section{Citation}

Moran, Richard. 1994. Arthur Collins's The nature of mental things. Philosophy and

Phenomenological Research 54(4): 917-920.

\section{Published Version}

http://www3.interscience.wiley.com.ezp-prod1.hul.harvard.edu/journal/118493456/home

\section{Permanent link}

http://nrs.harvard.edu/urn-3:HUL.InstRepos:3294436

\section{Terms of Use}

This article was downloaded from Harvard University's DASH repository, and is made available under the terms and conditions applicable to Other Posted Material, as set forth at http:// nrs.harvard.edu/urn-3:HUL.InstRepos:dash.current.terms-of-use\#LAA

\section{Share Your Story}

The Harvard community has made this article openly available.

Please share how this access benefits you. Submit a story.

Accessibility 
1987)

\author{
Book Symposium on Arthur Collins, The Nature of Mental Things (Notre Dame, \\ Philosophy and Phenomenological Research \\ Richard Moran, Princeton University
}

If I believe that my friend Pierre is fond of me, this means that his friendship appears to me as the meaning of all his acts. [...] But if I know that I believe, the belief appears to me as pure subjective determination without external correlative. This is what makes the very word 'to believe' a term utilized indifferently to indicate the unwavering firmness of belief ("My God, I believe in you") and its character as disarmed and strictly subjective ("Is Pierre my friend? I do not know; I believe so"). ${ }^{1}$

In The Nature of Mental Things, Arthur Collins provides a quite general argument against any and all philosophical theories of belief (and related psychological concepts) which identify believing $\mathrm{P}$ with some 'inner state' of the believer, whether neurophysiological, nonmaterial, functional, or behavioral-dispositional. Near the end of the book he summarizes one of the major strands in his argument:

But any understanding of belief that identifies believing that $\mathrm{P}$ with the presence of an inner state, activity, or condition would immediately authorize first-person reports of that state, activity, or condition. Given the identification, such reports would be assertions saying that the speaker believes that $\mathrm{P}$, but they would necessarily be neutral on $\mathrm{P}$ itself. This is what we showed to be unacceptable. (166)

What is found to be unacceptable is the possibility of first-person reports on the state of belief that $\mathrm{P}$ which involve no assertion of, or stand on, $\mathrm{P}$ itself; and any account of belief that would license such purely psychological reports is to be rejected. In fact, the argument is even more general than the animus against 'inner states' would suggest. For the same possibility would arise were belief identified with any 'external' state of the believer, or any combination of 'inner' and 'outer' facts. Collins's argument, then, will apply to any account of belief (and related attitudes) which takes belief that $\mathrm{P}$ to consist in something independent of $\mathrm{P}$ itself, and hence identifiable independently of the fact of $\mathrm{P}$.

Certainly we can and do identify the beliefs of others independently of the truth of what is believed. Should the fact that this is not an ordinary or rational possibility in one's own case mean that believing something is not a fact of some kind about the believer? What does it mean for someone to believe something?

1 Jean-Paul Sartre, Being And Nothingness, trans. Hazel Barnes, (New York: Philosophical Library, 1956); p. 114. 
Neither Collins nor his philosophical opponents mean to deny that there is such a thing as someone's being committed to the existence of some state of affairs, or simply, a person's taking something to be true. To say this is not yet to say anything about inner states, nor is it even to go as far as to say that there is anything at all that 'taking $\mathrm{P}$ to be true' consists in, any further thing in virtue of which the person takes it to be true. Nonetheless, even with such minimal philosophical baggage we can see that there would be something incoherent in a person's saying that while he himself was committed to the truth of $\mathrm{P}$, the actual truth of $\mathrm{P}$ was something on which he took no stand. Collins's reason for rejecting theories which identify belief with some 'inner state' of the person is that they would license statements of just this form. If this incoherence is offered as a reason for rejecting constitutive theories of belief, then we must ask what is different about the minimal gloss on the concept of belief offered above, in terms of commitment or simply taking to be true, such that it does not allow the incoherent conjunctive statements whereas the various constitutive theories allow them.

It does not seem to me that we have been given a reason to think that there is anything specific to the constitutive theories that would entail their licensing such statements in cases where the ordinary non-reductive understanding of belief in terms of 'taking to be true' would not. Such 'pure reporting' on one's own attitudes is no more or less a possibility even if we take belief to be an irreducible fact, an orientation of the person not constituted by anything else. On the one hand, it is not at all clear that a theory which identifies believing $\mathrm{P}$ with being in some brain-state will permit the person to affirm the belief-report while withholding assent to $\mathrm{P}$ itself, since by hypothesis he believes that $\mathrm{P}$ when he is in that brain-state, and hence will affirm it. And on the other hand, I think even an understanding of believing $\mathrm{P}$ which refuses to identify it with anything at all still ought not to preclude our describing various situations in which, for one reason or another, one's grip on the psychological attribution of belief to oneself is more secure than one's grip on the fact of $\mathrm{P}$ itself. This will not be a stable situation for the person, to be sure, and pressures arising from it will sometimes force withdrawal of the original attribution. But it is a liability of being a believer so long as my having a belief is something about me for which there may be evidence. No account of belief can avoid the fact that beliefs distinguish people from each other, and such differences between people are describable. This is not to say that there is nothing wrong with the 'pure reporting' of such differences in the first-person, but it is to say that the issue of 'identity theories' of belief is strictly irrelevant to this possibility and to the diagnosis of what is wrong with it.

The disjunctive analysis of belief-statements that Collins offers makes it harder to see this because in effect it fails to capture the sense in which beliefs relate to particular believers and distinguish them from others. He wants an account which will not have belief consist in any further fact about the believer, but which allows the truth value of 'I believe that $\mathrm{P}^{\prime}$ to differ from that of ' $\mathrm{P}$ ' itself. The disjunctive account he gives, 'P, or I am much mistaken', does satisfy these requirements but it also has the consequence that from the fact that it is raining out I could infer any arbitrary person's belief that it is raining out. From any ' $\mathrm{P}$ ' I could conclude 'P, or Ed Koch is much mistaken'. Thus, in seeking to rescue belief from philosophical objectification, the account ends up de-personalizing it instead.

Being a believer means knowing that one's believing $\mathrm{P}$ is one thing, and the fact of $\mathrm{P}$ itself is another. A person's being committed to the truth of some proposition licenses various expectations of that person, both normative and empirical expectations. The empirical expectations (concerning, e.g., what I am liable to say and do) constitute evidence on the basis 
of which someone else may attribute some belief to me. My particular relation to such a person (e.g., as lover, or analysand, or confessor) may incline me in some situations to trust to their judgement about what my attitude is to a degree that does not neatly match my degree of confidence about the proposition in question. I may suspect myself of being self-deceived, or conflicted, or simply inattentive and confused. In such a case my position would resemble that of the person who has discovered in himself the brain-state which he identifies with the belief that P. Such lack of harmony between the reports of myself which I am inclined to make (or accept from others) and what I am prepared to assert about the world beyond my attitudes is certainly something that calls for resolution on my part. But the straits that such a person has got himself into do not depend on identifying belief with anything other than his taking something to be true, but only on seeing that attitude as something that distinguishes him from certain other people in recognizable ways.

One of the major themes of Sartre's discussion of bad faith (from which the opening quotation is taken) is that there is indeed something incoherent in the attempt at a merely psychological, or 'reporting' relation to my own attitudes and other commitments, (seeing them merely as 'facticities' which characterize me), but that such a tendency is discernable in familiar and problematic aspects of our lives. Rather than seeing the first-person considerations so subtly deployed by Collins as being incompatible with certain positions in the metaphysics of mind, I think we should see them instead as aspects of what we might call the existential situation of being a believer, where this is understood as necessarily having both an empirical aspect (as a psychological fact about me) as well as a 'transcendental' aspect, expressive of my relation to the world. Collins is right to insist that any adequate philosophy of mind must accommodate the complex relations between expressions of one's attitudes and any descriptive stance toward mental life, but I don't feel he has demonstrated the relevance of this requirement to the question of the acceptability of any 'constitutive' account of belief. However, I look forward to hearing more about the development of this view. 